\title{
PODE A MULHER NEGRA GAÚCHA FALAR? OFERTANDO OUVIDOS PARA ATENTAR AOS ESPECTROS DE SUAS VOZES SILENCIADAS
}

\author{
DÊNIS MOURA DE QUADROS (FURG) ${ }^{1}$
}

\begin{abstract}
RESUMO: Ao pensarmos as obras produzidas por mulheres negras temos certa dificuldade de listálas e ao listar precursoras como Carolina Maria de Jesus (1914-1977) e Conceição Evaristo (1946) constatamos que as autoras publicam no eixo Rio-São Paulo. Ao nos direcionarmos ao sul do Brasil, a lista lacunar ecoa mais ausências. Contudo, em 2016, o ponto de cultura negra "Sopapo Poético" publica sua primeira antologia de poemas Sopapo Poético: Pretessência (2016) em que dos nove organizadores, quatro são mulheres e dos dezenove poetas, dez são mulheres. Assim, recortamos quatro poetas da antologia que também a organizam: Delma Gonçalves, Fátima Farias, Lilian Rocha e Pâmela Amaro. Além do gênero e da raça, a ancestralidade Ihes serve como inspiração para suas poesias resistentes.
\end{abstract}

PALAVRAS-CHAVE: Literatura afrofeminina. Dessilenciamento. Sopapo Poético.

ABSTRACT: When we think of the works produced by black women, we have a certain difficulty in listing them and by listing precursors such as Carolina Maria de Jesus (1914-1977) and Conceição Evaristo (1946-) we found that the authors publish on the Rio-São Paulo axis. As we direct to the south of Brazil, the chasm list echoes more absences. However, in 2016, the black culture point "Sopapo Poetico" publishes its first anthology of poems "Sopapo Poetico: Pretessência" (2016) in which of the nine organizers, four are women and nineteen poets, ten are women. Thus, we cut four poets from the anthology that also organize it: Delma Gonçalves, Fátima Farias, Lilian Rocha and Pâmela Amaro. In addition to gender and race, ancestry serves as an inspiration for their sturdy poetry.

KEYWORDS: Afrofeminina Literature. Dessilenciamento. Sopapo Poético.

\section{CONSIDERAÇÕES INCIAIS}

Gayatri Spivak (1942- ) em Pode o subalterno falar? (2010) faz um apanhado das condições que não permitem aos sujeitos subalternizados falarem ou mesmo terem suas vozes autorais audíveis e conclui com a afirmativa de que o subalterno não pode falar, pois sua fala não tem valor atribuído no sistema social que o oprime. Logo, se essas mulheres negras falam e publicam é, no mínimo, um ato de insubmissão e resistência. Mesmo não Ihes sendo permitido falar, elas tomam "de assalto" o poder da escrita e, como intelectuais (SANTOS, 2018), (d) escrevem suas realidades e se autorrepresentam, com isso, rompem com estereótipos impostos e criam novos mecanismos de resistência ecoando suas vozes.

Como pesquisador negro, fator que atravessa minha produção acadêmica, começo pensando em como lhes dar voz, mas logo percebo que elas não precisam de voz, elas a têm e imponentes, afrontosas, então, dedico-lhes, como forma de sacrifício, como presente, como oferenda: meus ouvidos. Como Obá ${ }^{2}$, corto um pedaço de mim para ser servido neste banquete em que elas não estão nas cozinhas ou na praça mexendo os tachos, fritando seus acarajés,

\footnotetext{
${ }^{1}$ Doutorando em Letras, área de concentração História da Literatura, pela Universidade Federal do Rio Grande (FURG), orientado pelo prof. Dr. Antônio Carlos Mousquer. Bolsista CAPES, e-mail: denisdpbg10@gmail.com 2 Orixá feminino que divide com Oxum e lansã o amor de Xangô. Obá em um dos ítãs é "enganada" por Oxum que lhe indica que o amalá, prato preferido do amado, deveria levar um pedaço de suas orelhas ao que Obá se automutila. Ao final, Xangô expulsa de seu reino Obá e Oxum.
} 


\section{$=$ TRAMA $=$}

elas estão sentadas sobre a roda da Ancestralidade (com A maiúsculo), afrocentrando a crítica e abrindo espaço para que suas vozes ecoem.

Assim, o recorte teórico elencado para a análise das quatro poetas negras gaúchas é composto pelas reflexões de Gayatri Spivak (1994; 2010); Djamila Ribeiro (2017); Mirian Cristina dos Santos (2018) para pensarmos no dessilenciamento das vozes autorais das mulheres negras; Sueli Carneiro (2011), Conceição Evaristo (2005) e Heloísa Toller Gomes (2004) para discorrermos sobre o processo de subalternização dessas mulheres, condicionadas a repetirem histórias de dor de suas antepassadas escravizadas, e sua escrita atravessada por essa condição; e, por fim, o conceito de literatura afrofeminina (2012) cunhado por Ana Rita Santiago.

O principal objetivo desse trabalho é "(...) divulgar a produção intelectual de mulheres negras, colocando-as na condição de sujeitos e seres ativos que, historicamente, vêm pensando em resistências e reexistências." (RIBEIRO, 2017, p. 90), ou seja, para analisar as produções de duas mulheres negras gaúchas, elencamos uma base teórica composta por mulheres e, hegemonicamente, pesquisadoras negras brasileiras.

Há em Porto Alegre-RS, um grupo que se reúne nas primeiras terças-feiras de cada mês (r) existindo. Esse ponto de cultura denomina-se Sopapo Poético. Em 2016, o Sopapo conseguiu publicar uma antologia desses poetas (dezenove ao total) na antologia poética Sopapo Poético: Pretessência (2016), contando com dez poetas negras. Mas afinal, o que as negras gaúchas têm a falar? É o que pretendemos analisar no recorte de quatro das dez mulheres que, também, participam da organização da antologia: Delma Gonçalves, Fátima Farias, Lilian Rocha e Pâmela Amaro, percebendo a coletividade e a particularidade de cada autora.

\section{FALAR/PUBLICAR É UM ATO DE RESISTÊNCIA E INSUBMISSÃO}

Ao questionar a fala do subalterno, em especial das mulheres negras, Spivak (2010) conclui que suas falas não são permitidas, pois são desprovidas de poder de fala. Contudo, essas mulheres negras falam e, apesar da dificuldade, publicam suas obras em que rompem com o silêncio imposto e se autorrepresentam, rompendo, também, com estereótipos racistas e sexistas reproduzidos socialmente e ficcionalmente. Ao concluir que a fala do subalterno não tem nenhum valor atribuído, a crítica indiana, não está afirmando que ele não deve falar, ao contrário, como ela mesma afirma "(...) os oprimidos podem saber e falar por si mesmos." (SPIVAK, 2010, p. 44), contudo há uma estrutura que não permite que suas vozes ecoem. Mesmo falando, o discurso do subalterno é, de uma forma ou outra, menosprezado, abafado e tornado inaudível. Mas, espectros ressoam e, com certo desprendimento eurocêntrico essas vozes podem ser ouvidas.

Se por um lado, a fala dessas mulheres é silenciada pelo patriarcado que mantêm seu poder hegemônico, sobretudo, na literatura através dos cânones cristalizados de autores homens e brancos, por outro, a cor de suas peles e autoidentificação negra dessas autoras Ihes priva, também, do centro, diminuindo as poucas possibilidades de falar, quiçá publicar. Nessa "encruzilhada" de opressões que, respeitando as particularidades de cada autora, somam-se outras, os "muros" se erguem e os espectros tornam-se, ainda mais, inaudíveis. Mas é preciso confirmar que elas falam e suas vozes são altas o bastante para serem ouvidas não necessitando de "intermediários", mas de verdadeiros "ouvidos" atentos evocando outros ouvidos.

É inegável que as ondas feministas reavaliaram historicamente inúmeras autoras que publicavam com pseudônimos, bem como a garantia de direitos importantes como, por exemplo, o direito ao voto, mas é preciso dizer que a pauta das mulheres negras não foram 


\title{
$=$ TRAMA $=$
}

contempladas nesse movimento. Mirian Cristina Santos (2018), em sua tese de doutorado, reavalia a presença de intelectuais negras no Brasil e afirma que: "Como as mulheres negras possuem demandas diferentes, o feminismo negro se torna necessário e coerente nas reivindicações de sua alteridade" (SANTOS, 2018, p. 16) afirmação essa que corrobora com Spivak (1994), em Quem reivindica alteridade, ao afirmar que: "Separada do centro do feminismo, essa figura, a figura da mulher da classe subalterna, é singular e solitária" (SPIVAK, 1994, p. 191). Logo, surge a necessidade de união e surgimento de um feminismo interseccional ou feminismo negro que centralize as pautas e as lutas singulares dessas mulheres. Dessa forma, o lugar de fala surge como espaço de discussão necessário para legitimar seus discursos, contudo ainda é confundido como restrição de outras vozes.

O lugar de fala não proíbe que um pesquisador do sexo masculino, cisgênero, negro periférico fale de feminismo negro, mas exige que ao falar de feminismo negro apresente-se o trabalho das muitas mulheres que vieram antes de nós e que abra espaço para que outras mulheres negras falem e que, assim, suas vozes sejam legitimadas. "Pensar lugar de fala seria romper com o silêncio instituído para quem foi subalternizado" (RIBEIRO, 2017, p. 90) e não é possível romper silêncio com bases teóricas coloniais. Torna-se imprescindível enegrecer, pois, como afirma Sueli Carneiro (2011), a história se renova sem rupturas, mantendo a estrutura colonial em que os sujeitos negros ainda ocupam subempregos e espaços subalternizados sem a oportunidade de romper com essa realidade.

\begin{abstract}
O que poderia ser considerado como uma história ou reminiscências do período colonial permanece, entretanto, viva no imaginário social e adquire novos contornos e funções em uma ordem social supostamente democrática, que mantém intactas as relações de gênero segundo a cor ou a raça instituída no período da escravidão. As mulheres negras tiveram uma experiência histórica diferenciada que o discurso clássico sobre a opressão da mulher não tem reconhecido, assim como não tem dado conta da diferença qualitativa que o efeito da opressão sofrida teve e ainda tem na identidade feminina das mulheres negras (CARNEIRO, 2011, p. 20).
\end{abstract}

Essa experiência diferenciada reflete-se em suas escritas e produções em que, segundo Heloísa Gomes (2004): "A escrita (da mulher) negra é construtora de pontas. Entre o passado e o presente, pois tem traduzido, atualizado e transmutado em produção cultural o saber e a experiência de mulheres através das gerações" (GOMES, 2004, p. 13), essas pontes resgatam a ancestralidade, visto que as atuais possibilidades, mesmo que escassas, partem das inúmeras lutas das mulheres cujos passos vieram antes de nós. Ao falarem de si, recolhem outras vozes de suas ancestrais e de suas contemporâneas que sofreram e sofrem as mesmas opressões diárias, mas, ao falarem de si também rompem com estereótipos cristalizados e se autorrepresentam engendrando outras representações mais condizentes com suas experiências e reminiscências de suas raízes. Assim, é preciso pensar suas produções de maneira autônoma, sabendo que os conceitos acerca de literatura advinda de sujeitos afrodescendentes são inúmeros e difusos, bem como, discutíveis. Mesmo assim, elencamos o conceito advindo de uma pesquisadora negra, Ana Rita Santiago (2012), de literatura afrofeminina.

A literatura produzida por mulheres negras, doravante literatura afrofeminina, adotando o conceito da professora Dra. Ana Rita Santiago (2012), é pouco estudada na Academia brasileira. Há, atualmente, algumas aberturas como Quarto de despejo: Diário de uma favelada (1960) de Carolina Maria de Jesus, leitura obrigatória em vários vestibulares como, por exemplo, o da UFSC (Universidade Federal de Santa Catarina) para o ingresso em 2019. Santiago (2012) elenca como precursoras três autoras negras: Maria Firmina dos Reis (1825- 


\title{
$=$ TRAMA $=$
}

1917); Carolina Maria de Jesus (1914-1977) e Antonieta de Barros (1901-1952). No ano do centenário de morte de Maria Firmina (2017) pouco se ouviu falar de suas obras ou mesmo do primeiro romance abolicionista brasileiro Úrsula (1859), o que tem mudado paulatinamente. Também são raras as homenagens a esta autora basilar na literatura brasileira nos inúmeros eventos acadêmicos ao longo do ano de 2017.

\begin{abstract}
Nesse contexto, a literatura afrofeminina é uma produção de autoria de mulheres negras que se constitui por temas femininos e de feminismo negro comprometidos com estratégias políticas civilizatórias e de alteridades, circunscrevendo narrações de negritudes femininas/ feminismos por elementos e segmentos de memórias ancestrais, de tradições e culturas africano-brasileiras, do passado histórico e de experiências vividas, positiva e negativamente, como mulheres negras. Em um movimento de reversão, elas escrevem para (des) silenciarem as suas vozes autorais e para, através da escrita, inventarem novos perfis de mulheres, sem a prevalência do imaginário e das formações discursivas do poder masculino, mas com poder de fala e de decisão, logo senhoras de si mesmas (SANTIAGO, 2012, p. 155).
\end{abstract}

Sendo assim, a literatura afrofeminina, como reflete a própria Santiago (2012): "não (...) quer repetir histórias e vivências, mas desconstruí-las, quando oportuno, afirmar ancestralidades e práticas socioculturais afro-brasileiras, quando necessário, e inventar memórias de autoconstituição também como narrativas de si/nós" (SANTIAGO, 2012, p. 28). Logo, é pensando em dessilenciar as vozes autorais que analisaremos quatro poetas da antologia poética Sopapo Poético: Pretessência (2016), percebendo as individualidades e coletividades dos poemas de cada poeta.

\section{NÃO É SÓ PAPO: AS MULHERES QUE COMPÕEM A PRETESSÊNCIA AO SUL}

O Sopapo Poético surgiu em 2012 atrelado à necessidade de circulação dos poemas dos artistas e militantes do movimento negro do Rio Grande do Sul. De acordo com Fontoura; Salom; Tettamanzy (2016), após tomarem conhecimento dos muitos saraus negros espalhados pelo Brasil como, por exemplo, o Sarau Bem Black apresentado por Nelson Maca (1965- ) na $57^{\text {a }}$ Feira do Livro de Porto Alegre em 2011, unem-se para a criação do ponto de cultura que carrega em seu nome o sopapo, tambor confeccionado originalmente em madeira e couro de cavalo construído por africanos escravizados que trabalhavam nas Charqueadas na região de Pelotas-RS; O nome do sarau surge como homenagem ao ancestrais Giba-Giba, Gilberto Amaro do Nascimento (1940-2014); Bedeu, Jorge Moacir da Silva (1946-1999) e outros, bem como resgata culturalmente os toques e cantos do Maçambique, o congado ${ }^{3}$ que ocorre em Osório-RS.

O sarau segue uma estrutura previamente organizada que é marcada em seu início pelo toque do Sopapo que inicia oficialmente o encontro ritualísticos poético. Após, ocorrem as saudações aos Orixás. "Quem propõe a saudação religiosa deve ser uma pessoa mais velha" (FONTOURA; SALOM. TETTAMANZY, 2016, p. 164) que marca o respeito e a sabedoria dos mais velhos. Os Orixás saudados são Bará (que abre os caminhos); Xangô (Orixá dono do tambor) e Oxum (Orixá do ouro e da beleza, protetora das crianças e da continuidade da tradição). "A estrutura do sarau consiste em três momentos dinamicamente encadeados: primeiro, a roda aberta de intervenções poéticas; segundo, a acolhida do 'Sopapinho' (entrada

\footnotetext{
${ }^{3}$ Manifestação cultural e religiosa de matriz africana e cristã em que anualmente coroa-se um rei e uma rainha, ambos negros, que acompanham os festejos ao som de instrumentistas que conduzem as danças e contradanças.
} 


\section{$=$ TRAMA $=$}

das crianças na roda do sarau), e, por último, a apresentação do homenageado da noite" (FONTOURA; SALOM; TETTAMANZY, 2016, p. 162).

O terceiro momento, de homenagens, marcam o ápice e o encerramento do sarau. Os três momentos delineiam, também, a abertura de espaço para os mais velhos e os mais novos permitindo uma enriquecedora troca de experiência e manutenção da cultura afrodescendente. O recorte do presente artigo traz as quatro poetas que publicam e organizam a obra poética e, em especial, Pâmela Amaro Fontoura, que também reflete teoricamente sobre o fazer poético do sarau. Três delas nasceram na capital do estado do Rio Grande do Sul, Porto Alegre, graduadas em diversas áreas, entre elas, letras. Quem rompe com o padrão é Fátima Farias que nascera em Bagé-RS, cidade do interior do Rio Grande do Sul na região conhecida como Campanha e, a vida não Ihe proporcionara as oportunidades de ter concluído o Ensino Superior como as demais, mas esse fato não a torna menos capaz, pelo contrário, sua poesia é repleta de escrevivência, amparada pela memória ancestral. Para melhor percebermos a qualidade ética e estética dos poemas apresentaremos, em um primeiro momento, as autoras e suas obras poéticas para, em um segundo momento, perceber semelhanças e rupturas no tecer poético de forma geral.

Delma Gonçalves nascera na capital do Estado, Porto Alegre-RS, poetisa e compositora é graduada em Letras (ULBRA) com pós-graduação (FAPA), em 2006 teve sua poesia Lanceiros negros premiada no concurso organizado pela FAFIMAN (Faculdade de Filosofia, Ciências e Letras). Tem publicado o livro Cinco décadas de samba no bairro Santana (2010) e outras publicações dentro de diversas coletâneas. No Sopapo poético: Pretessência (2016) tem oito de seus poemas publicados, dentre eles, o premiado Lanceiros negros. Elencamos dois para análise: Não é só- papo em que tematiza o sarau e Axé em que tematiza a resistência ancestral das mulheres negras.

No primeiro poema a voz poética repete o verso "Não é só- papo", ao passo que vai relatando o significado e a importância da existência do sarau. A voz poética busca reencontrarse com a África, construindo pontes, ou tentando, com o passado em que os africanos eram livres de verdade. Nesse tempo, a vivência que ocorria em tribos disseminavam a cultura étnica através das figuras centrais de seus reis e rainhas, respeitando sempre aos mais velhos e aos Ancestrais tendo-os como referência. Logo, a reunião dos descendentes desses africanos escravizados faz alusão a esse tempo primordial.

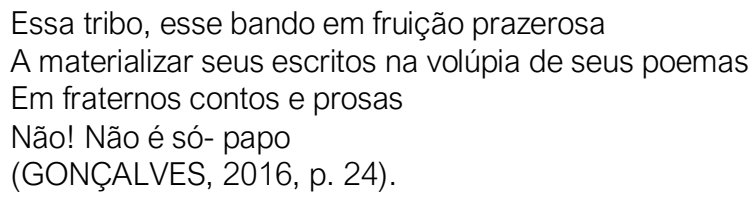

Além da materialização da arte através dos escritos lidos em voz alta no sarau, a voz poética recupera essa oralidade que surge nos encontros, bem como outras formas de arte e, sobretudo, o contar, forma que remete ao gritot. Não podemos esquecer que a cultura de matriz africana sobreviveu e sobrevive de forma oral tendo hoje algumas aberturas para a escrita, mas permanecendo oral. Ao afirmar que o exercício da literatura no sarau: "A ilustrar histórias dos ancestrais, por essa via" (GONÇALVES, 2016, p. 24), a voz poética retoma um dos mais importantes alicerces da cultura negra: a ancestralidade. Nesse ínterim, a voz poética desvela o principal objetivo do sarau: 


\section{$=$ TRAMA $=$}

E dar a cara a tapa aos preconceitos

Focar um novo conceito, que a vista de muitos não alcança

Pela dificuldade de ainda não sermos, por alguns, aceitos

(GONÇALVES, 2016, p. 25).

O ato de lavar retorna à ancestralidade, fazendo alusão às orixás femininas, em especial, Oxum que é reverenciada no início de cada encontro do sarau. Outro ponto que a voz poética destaca é que essa ancestralidade negra não compactua com a cultura judaico-cristã cuja base é patriarcal, ou seja, destaca a figura ancestral da avó e a base do matriarcado. Ao fim, finaliza que o sarau não é só "papo", não é apenas um espaço para fala, mas uma fala demarcadamente política e, como afirma Gomes (2004), construtora de pontes.

O matriarcado que garantiu a resistência da cultura de matriz africana é tema do poema Axé em que a voz poética destaca, além da ancestralidade, a força das mulheres negras que resistem aos subempregos, herança da colonização que, como afirma Carneiro (2011), permanece no imaginário e na estrutura social do Brasil.

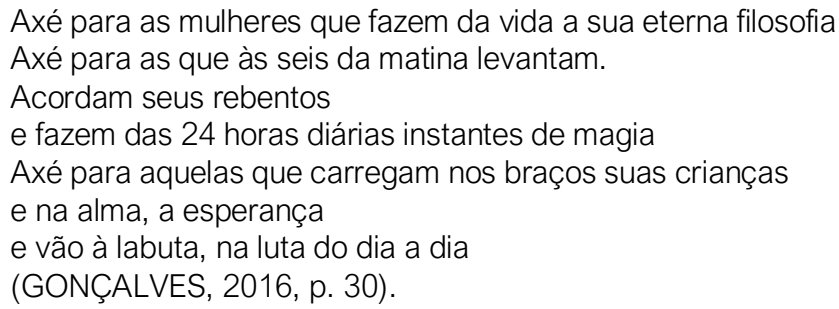

O "axé" é o poder vital que reside em cada um de nós e que provêm do Orixás (Donos (as) do Ori, topo da cabeça). A voz poética deseja "axé" a essas muitas mulheres que, como guerreiras, fazem de suas vidas "magia", ou seja, desdobram-se em muitas para sobreviver no duro cotidiano em torno de seus filhos, muitos, abandonados pelos pais. Ainda, retoma às muitas mulheres que sofrem violência sexual e são desacreditas pelos seus pares e por aqueles que deviam legislar por elas. "Axé para aquelas que, ao serem estupradas, são desacreditadas" (GONÇALVES, 2016, p. 31). Encerra elencando vários nomes femininos, dentre elas de algumas poetas da antologia e as classifica "guerreiras mulheres!" (GONÇALVES, 2016, p. 31).

Fátima Farias nascera em Bagé-RS, cidade do interior do Rio Grande do Sul que faz fronteira com o Uruguai, conhecida, também, pelo epíteto de Rainha da Fronteira. Sua mãe era dona de casa e seu pai torneiro hidráulico, boêmio e carnavalesco e é dele que herda sua paixão pelo carnaval. Fátima Farias homenageia suas raízes e sua descendência no poema Para Luisa, minha neta. Dos 15 poemas publicados na antologia recortamos Colheita, que faz alusão a sua terra natal, e Sou papo, sou poeta em que a poeta reflete seu fazer poético e suas experiências.

Poema colheita, a voz poética retoma um período que se estende no Rio Grande do Sul, em especial, na região campanha: as inúmeras lavouras de arroz e soja. A voz poética começa de forma lógica afirmando que é preciso plantar para que se tenha comida no prato, contudo, sabemos que grande parte da população brasileira é urbana e vive do que é produzido nas regiões periféricas como é o caso da cidade natal da poeta, Bagé, e as cidades em seu entorno. Essas lavouras, durante muito tempo, foram semeadas pelas mãos negras em que os (novos) senhores de engenho viviam (vivem) do lucro dessas lavouras. 


\section{$=$ TRAMA $=$}

Calejadas

Pelas lavouras da vida!

(FARIAS, 2016, p. 55).

As mãos calejadas e as lavouras da vida são, também, marcas da colonização em que a profissão hostil e braçal ainda é desempenhada pelos descentes desses ex-escravos. Cada dia mais, a iminência da liberação de agrotóxicos nocivos à saúde nos alerta aos primeiros que morrerão: corpos negros. A voz poética não problematiza o fato, mas demarca as mãos calejadas do trabalho pesado em que a caneta não cabe e a voz é silenciada pelo peso dos dias. As muitas lavouras da vida se desdobram na necessidade de pôr a comida na mesa e sobreviver e dá sustento aos seus descendentes que, na roda social, herdam suas profissões e suas dores.

O segundo poema, Sou papo, sou poeta, a voz poética destaca, também, a importância dos saraus e se autoidentifica afirmando: "Sou mulher e poesia/ (...) Sou negra, não descartável" (FARIAS, 2016, p. 59), essa afirmação nos lembra outros poemas da literatura afrofeminina em que a voz poética retoma sua ancestralidade, sua negritude e demarca seu lugar de fala. Além disso, a voz poética deixa bem claro que por ser mulher e negra falando em uma sociedade que não lhe atribui valor ela não é "descartável".

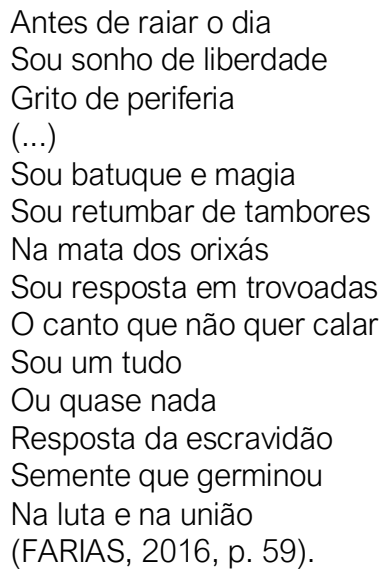

A voz poética responde, em parte, a pergunta que permeia esse trabalho: a mulher negra gaúcha pode falar e ela fala e, em sua fala, recolhe outras vozes que assume para si o eco silenciado das ancestrais. Ser sonho de liberdade reflete a falta dela desde que o primeiro africano/africana fora trazida forçado e escravizado ao Brasil violando a liberdade e a privação de sua terra. Elemento esse (terra) que retorna ao poema na imagem da semente plantada e germinada com sangue que se ergue resistente "Na luta e na união", união essa possibilitada pelos encontros do sarau. Essa voz poética feminina que se confunde com a voz da autora negra gaúcha toma para si a força de um canto que não aceita a impossibilidade e que, mesmo com as inúmeras tentativas de silenciamento, se levanta e é resposta contra as marcas da escravização. Ainda, essa voz ecoa a ancestralidade dos Orixás, retumbando, sobretudo, resistência.

Lilian Rocha é natural de Porto Alegre-RS, farmacêutica e analista clínica (UFRGS), especialista em Homeopatia (ABH), musicista em que destacamos as canções Capitão do mato e Tropa de São Benedito, ambas em parceria com José Carlos Rodrigues. Além disso, Lilian Rocha é facilitadora didata de Biodanza. Publicara dois livros autorais: A vida pulsa (2013) e Menina de tranças (2018). Dos nove poemas publicados na antologia elencamos Mulher, em 


\title{
$=$ TRAMA $=$
}

que a poeta destaca a força das mulheres, e Ancestralidade, em que a poeta resgata as raízes africanas.

O poema Mulher reverencia as mulheres, sobreviventes das opressões sofridas constantemente em uma sociedade machista e de estrutura patriarcal. Em determinado ponto do poema, a voz poética reafirma-se como uma dessas mulheres sobreviventes. Essa imagem da sobrevivência retoma o ato de insubmissão das mulheres negras, em especial, que publicam seus escritos dessilenciando suas vozes autorais. Sobreviver não é opcional, ao contrário, a luta diária pela sobrevivência, ainda, é algo imposto a essas mulheres.

\author{
Somos sobreviventes \\ Muitas vezes \\ Com um sorriso \\ Ou com uma lágrima \\ Molhando o nosso rosto. \\ Mas como guerreiras \\ Novamente \\ Viramos a página \\ (ROCHA, 2016, p. 120).
}

Não poderia haver um termo mais aproximado para nos referirmos a essas sobreviventes: "guerreiras". O misto de alegria e de tristeza que irrompe na poesia denotando a intensidade de seus dias culmina na virada de página, páginas essas que insistem em apagar os feitos daquelas e daqueles que vieram antes e que sobreviveram às opressões coloniais. $O$ ato de virar a página remete a continuidade da sobrevivência e ao ato do fazer poético em que essas mulheres "viram a página" apresentando outra face da literatura, face insurgente e inegável. A voz poética afirma: "Aqui estamos" (ROCHA, 2016, p. 120) e reúne em sua voz outras vozes que desempenha o papel de mães, filhas, trabalhadoras e cientistas, papel de sobrevivente na "encruzilhada" das opressões sexistas e racistas.

O poema Ancestralidade resgata as raízes africanas ou a busca por essas raízes. O processo de escravização apagou totalmente os laços com a África de nossos ancestrais em que, atualmente, não temos como saber especificamente nossas origens étnicas sabendo apenas que é de matriz africana. Mas África é um enorme continente tratado, muitas vezes, como uma cidade devastada e assolada, cuja pobreza é resultado de anos de colonização europeia. Mesmo assim, a voz poética consegue ligar-se ao Ancestral, em especial, nos momentos de união como, por exemplo, nos encontros ritualísticos do sarau.

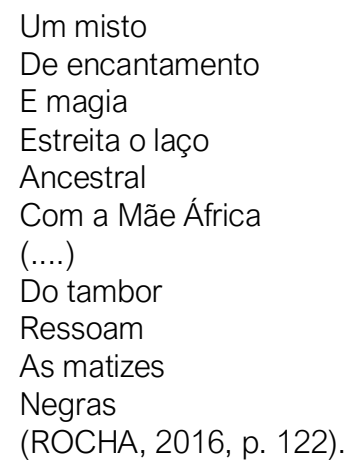

A presença do tambor, evocado pela voz poética, alude tanto ao sopapo presente no ritual poético, quando ao ilú nos terreiros de Batuque Gaúcho ou ao atabaque nos terreiros de Candomblé, bem como outros tambores como, por exemplo, o da congada. Ou seja, a figura do tambor perpassa as várias manifestações de matriz africana que se desenvolvem de 


\section{$=$ TRAMA $=$}

diferentes maneiras em todo o Brasil. O ressoar do tambor ecoa as vozes ancestrais recolhidas pela voz poética que, como nos outros poemas, é confundida com a voz autoral. "Como guerreiros nagôs" (ROCHA, 2016, p. 122) resgata a força da ancestralidade e a busca por essa memória coletiva dilacerada e, mesmo assim, resistente, força e energia essa que encerra o poema com "Asé!" (ROCHA, 2016, p. 122), força vital dos Orixás.

Pâmela Amaro é atriz, cantora, compositora, arte-educadora e poeta. Formada em Teatro (UFRGS), natural de Porto Alegre. É uma das vozes femininas no samba afro-gaúcho. Dos oito poemas elencamos Amor negro, em que Pâmela Amaro resgata sua herança ancestral rompendo com a visão da dor herdada, e Sarau Sopapo, em que ao falar do sarau resgata sua importância e o espaço político e de resistência.

No poema Amor negro, a voz poética ressignifica o ser negro e as imagens engendradas pela palavra marcada pela opressão colonial. Essa ressignificação parte, principalmente, da união desses irmãos de cor escura que passaram pelo processo de negritude em que se reconhecem como sujeitos negros. Sujeitos esses que sofrem cotidianamente com o racismo que levanta barreiras e diminui suas oportunidades de ascender. É, então, à partir de: "Um negro olhar, um desabafo entre irmãos/ Que se reconhecem na mesma etnia" (AMARO, 2016, p. 164). É, então, a dor que une esses sujeitos que sobrevivem e resistem unidos. Assim, é interessante pensar o sarau como um momento de união, de reforçar não só os laços com a Ancestralidade africana, mas os laços com os contemporâneos em uma luta contra o: "Racismo duro" (AMARO, 2016, p. 164).

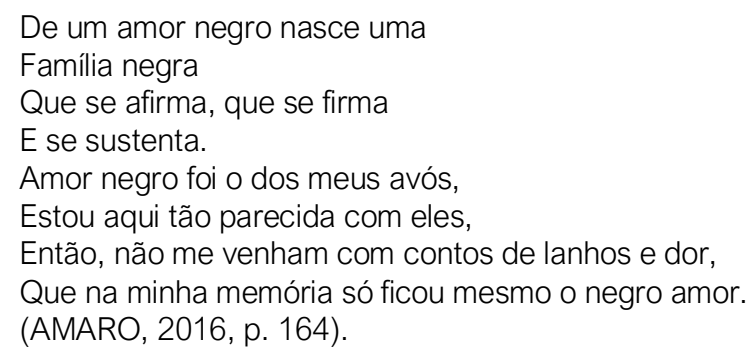

Essa família negra tem duplo significado: a de uma família que assume a identidade negra e a nutre e a mantêm com seus descendentes; e também, da união de sujeitos negros que se autoidentificam com sua ancestralidade de matriz africana. Esse amor que nutre os laços da família negra é genuíno e Ancestral. Dos exemplos do amor advindo da negritude, a voz poética rejeita os estereótipos históricos que insistem em figurar os negros de forma precária, sofrendo violências e violações físicas debaixo do "chicote do feitor". Logo, nutre na memória individual a herança do amor ancestral que reconstrói a memória coletiva dilacerada. A escrita da mulher negra é construtora de pontes (GOMES, 2004) em busca de suas raízes dilaceradas pelas opressões, em um primeiro momento, sexistas e racistas.

O que as quatro poetas têm em comum além de terem participado da obra poética Sopapo Poético: Pretessência (2016), organizando-a é o fato de tematizarem sobre suas vivências. Ou seja, suas poesias são orientadas pela escrevivência (EVARISTO, 2005) e, ao falarem de si, remontam histórias passadas e ancestrais de outras. Além disso, percebe-se uma preocupação com a permanência de seus legados artísticos o que se reflete na estrutura do sarau. As quatro autoras retomam a história das mulheres, em especial, das ancestrais em que as vozes poéticas mesclam-se à identidade das autoras, bem como recolhem as muitas vozes do sarau e rompem com o silenciamento. 


\section{$=$ TRAMA $=$}

\section{CONSIDERAÇÕES FINAIS}

A mulher negra não pode falar, não há poder que permita com que seu discurso seja ouvido, quer dizer, não lhe é permitido falar e quando elas insistem em ecoar suas vozes seus discursos são deslegitimados. O subalterno não pode falar (SPIVAK, 2010) e as mulheres negras encontram-se no entre lugar oprimidas pelo fato de serem mulheres e suas pautas não serem discutidas como centrais nos movimentos feministas e oprimidas por serem negras em que suas pautas também não são postas em discussão. Mas as mulheres falam e é preciso legitimar seus discursos através de seu lugar de fala (RIBEIRO, 2017), forma de dessilenciar suas vozes autorais e "tomar de assalto" o status de intelectuais. Como afirma, Mirian Santos (2018): "Ao politizar os espaços público e privado na leitura das narrativas negrofemininas (...) é possível empreender a denúncia do estereótipo do corpo negro, principalmente o feminino, tido como sujo e violado, por isso, ocupando o espaço das margens ou da submissão" (SANTOS, 2018, p. 167).

Ao denunciar o espaço, ainda, imposto das margens e da subalternidade, as narrativas negrofemininas advindas da literatura afrofeminina (SANTIAGO, 2012) rompem com os estereótipos engendrados e mantidos pelos mitos da democracia racial e do negro. Ao romper com esses (estereótipos), autorrepresentam-se e desnudam em suas vozes formas de resistência, construindo pontes (GOMES, 2004) principalmente com o passado, ou melhor, com a Ancestralidade e a busca de suas raízes africanas. As mulheres negras não só podem falar como falam e suas vozes ecoam, mesmo com as inúmeras tentativas de silenciá-las, e recolhem outras vozes que (con) fundem-se às vozes autorais das autoras. Quando falam, "assenhoram-se" do poder da escrita, como afirma Conceição Evaristo (2011):

Sendo as mulheres invisibilizadas, não só pelas páginas da história oficial, mas também pela literatura, e quando se tornam objetos da segunda, na maioria das vezes, surgem ficcionalizadas a partir de estereótipos vários, para as escritoras negras cabem vários cuidados. Assenhorando-se "da pena", objeto representativo do poder falo-cêntrico branco, as escritoras negras buscam inscrever no corpus literário brasileiro imagens de uma autorrepresentação. Surge a fala de um corpo que não é apenas descrito, mas antes de tudo vivido. A escre (vivência) das mulheres negras explicita as aventuras e as desventuras de quem conhece uma dupla condição que a sociedade teima em querer inferiorizada, mulher e negra (EVARISTO, 2005, p. 205, grifos da autora).

O Sopapo Poético é um espaço de diálogo, de resistência do povo negro massacrado pela dupla colonização europeia, político, artístico ritual. O sarau é ponto de cultura, é ponto de arte, é uma concentração afro-gaúcha. Seus três momentos demonstram a necessidade de respeitar os mais velhos e abençoar os mais novos, ou seja, partindo da Ancestralidade do tambor e dos Orixás perpassa aos contemporâneos e é repassado aos descendentes. A fala das quatro autoras aqui analisadas é unânime: Não vão nos calar. Suas vozes ecoam e é preciso ouvidos atentos para que a mensagem não se perca, não seja distorcida e, sobretudo, seja legitimada. A mulher negra deve falar e cabe à Academia não apenas ouvi-las, mas abrir espaço para que elas ocupem o centro sem relembrar da margem, sem ser subalternizada.

\section{REFERÊNCIAS}

AMARO, Pâmela. Pâmela Amaro. In: ROCHA, Lilian Rose Marques da. [et. al]. Sopapo poético: Pretessência. Porto Alegre: Libretos, 2016. P. 159-167.

CARNEIRO, Sueli. Enegrecer o feminismo: A situação da mulher negra na América Latina a partir de uma perspectiva de gênero. 2011. Disponível em <https://www.geledes.org.br/enegrecer-o-feminismo-situacao-damulher-negra-na-america-latina-partir-de-uma-perspectiva-de-genero/> Acesso em 10/04/2019. 
FONTOURA, Pâmela Âmaro; SALOM, Júlio Souto; TETTAMANZY, Ana Lúcia Liberato. Sopapo Poético: Sarau de poesia negra no extremo sul do Brasil. Estudos de Literatura Brasileira Contemporânea, n. 49, p. 153-181, set./dez. 2016.

EVARISTO, Conceição. Gênero e etnia: uma escre (vivência) de dupla face. In: MOREIRA, Nadilza Martins de Barros; SCHNEIDER, Liane (Org). Mulheres no mundo: etnia, marginalidade e diáspora. João Pessoa: Ideia, 2005, p. 201-212.

FARIAS, Fátima. Fátima Farias. In: ROCHA, Lilian Rose Marques da. [et. al]. Sopapo poético: Pretessência. Porto Alegre: Libretos, 2016. P. 46-61.

GOMES, Heloísa Toller. "Visíveis e invisíveis grades": Vozes de mulheres na escrita afrodescendente contemporânea. Caderno Espaço Feminino. Uberlândia: Ed. UFU, v. 12, n. 15, p.13-26, 2004.

GONÇALVES, Delma. Delma Gonçalves. In: ROCHA, Lilian Rose Marques da. [et. al]. Sopapo poético: Pretessência. Porto Alegre: Libretos, 2016. P.22-34.

RIBEIRO, Djamila. O que é lugar de fala? Belo Horizonte: Letramento: Justificando, 2017. (Feminismos Plurais)

ROCHA, Lilian Rose Marques da. [et. al]. Sopapo poético: Pretessência. Porto Alegre: Libretos, 2016. ROCHA, Lilian. Lilian Rose Marques da Rocha. In: ROCHA, Lilian Rose Marques da. [et. al]. Sopapo poético: Pretessência. Porto Alegre: Libretos, 2016. P.116-125.

SANTIAGO, Ana Rita. Vozes literárias de escritoras negras. Cruz das Almas: Ed. UFRB, 2012.

SANTOS, Mirian Cristina dos. Prosa negro-brasileira contemporânea. 2018. 180f. Tese (Doutorado em Letras)- Programa de Pós-Graduação em Estudos Literários, Universidade Federal de Juiz de Fora, Juiz de Fora, 2018.

SPIVAK, Gayatri. Quem reivindica alteridade? In: HOLLANDA, Heloisa Buarque de. Tendências e impasses: 0 feminismo como crítica da cultura. Rio de Janeiro: Rocco, 1994.

SPIVAK, Gayatri. Pode o subalterno falar? Trad. Sandra Regina Goullart Almeida, Marcos Pereira Feitosa, André Pereira Feitosa. Belo Horizonte: Ed. UFMG, 2010. 